\title{
The Design of Work Facilities at the Work Station of Pressing T-shirt in CV Royaltrack Bandung
}

\author{
R.F. Ansharullah *, F.A. Saputra, E. Achiraeniwati, N. As'ad, C. Furqon \\ Universitas Pendidikan Indonesia \\ Bandung, Indonesia \\ * rifkifauzians@upi.edu
}

\begin{abstract}
In a manufacturing industry, the quality of product is a main priority to get the best quality products, therefore properly the right selection of materials and a highly skilled workforce must be done. In the process, a highly skilled workforce must be accompanied by an ergonomic work facilities, so the workers will feel comfortable. This condition will lead the maximized productivity of the workers and the product made will have the best quality. This research was done in CV Royaltrack, a company which is specialized in the fashion industry in Indonesia and Malaysia with the products such as tshirts, polo shirts, shirts, pants, slippers, bags, shoes and belts. The problem in this company is having a not ergonomic work facility at the work station of pressing, which is proven by the results of the Nordic Body Map questionnaire. The questionnaire showing $14,29 \%$ of workers imbs who really do not have complaint of pain, while $85,71 \%$ of the workers' limb had complaint of pain to the level of complaints reached on level two (mildly ill) amounted $25 \%$ of the limb, level three (ill) amounted $53,57 \%$ of the limbs and level four (very ill) amounted to $7,14 \%$ of the limb. From the result of the risk level of work identification that used Rapid Entire Body Assessment (REBA) method there are four out of ten work activities that have a risk on high level by reaching the action on level three, so the work facilities must be improved at the work station of pressing. The result of this research suggest a layout of the new ergonomic work desk facility with emphasis on anthropometry workers aspects so that workers feel safe and comfortable..
\end{abstract}

Keywords—Work Facilities; Work Station; Ergonomic

\section{INTRODUCTION}

Measurement of fatigue in the skeletal muscle system in the field of ergonomics has one difficulty that is until now there is no direct measurement of the extent of fatigue aspects. There is no absolute measurement of fatigue [1]. The nordic questionnaire is the most commonly used questionnaire for discomfort or pain in the body [2]. This questionnaire has been standardized.

\section{LITERATURE REVIEW}

Rapid Entire Body Assessment was developed by [3]. Rapid Entire Body Assessment is a method developed in the field of ergonomics and can be used rapidly to assess the working position or posture of the neck, back, arm and an operator's wrist. This method is also influenced by coupling factor, external burden which supported by body and also worker activity. Assessment using REBA does not take long to complete and perform general scoring on the list of activities that indicate the need for risk reduction resulting from the operator's work posture [4]. REBA development takes place in four stages. The first stage is the taking of worker posture data by using video or photo aid, the second stage is determining the corners of the worker's body part, the third stage is the determination of the weight of the raised object, the determination of coupling and the determination of worker activity. And lastly, the fourth stage is the calculation of the REBA value for the relevant posture. With the acquisition of REBA values can be known level of risk and the need for actions that need to be done to improve work posture.

Some means of postural analysis have two ways, usually contradictory, general quality and sensitivity [5]. in the method of postural analysis can be compensated by low sensitivity, example; The Ovako Posture Work Analysis System (OWAS) [6] have many kinds of usage but the result can be low [4].

In order to achieve the optimal solutions, these programs should be based on ergonomics principles and should include a wide-range assessment of all elements of the work system [7] After a direct observation of the pressing station and screening station there is a working facility that is not ergonomic on the pressing work station causing the wrong work posture, then the focus of this research is to design an ergonomic work facility on the At The Work Station Of Pressing T-Shirt at CV Royaltrack.

\section{METHOD}

This is a qualitative research, in identifying workers' pain complaints using a Nordic body map questionnaire, then the REBA score was measured to analyze work posture, to improve work posture, which we incorrectly redesigned a new work station using anthropometric ergonomics with 200 samples of Indonesians.

\section{RESUlt AND DISCUSSION}

This is the result of the Nordic Body Map questionnaire, the questionnaire data Nordic Body Map is filled by three 
need not be repaired, press machine lever, pressing t-shirts, and pressing the lever of press machine may need improvement while work activities take t-shirts to be pressed, take masking paper, put $\mathrm{t}$-shirt on the floor and release masking paper on t-shirt made improvements.

This is a work facility design at the work station of pressing tshirt in CV Royaltrack Bandung:

indicates $4 / 28 \times 100 \%=14.29 \%$ of the worker's body members do not experience pain complaints, while $24 / 28 \times$ $100 \%=85.71 \%$ of the worker's body members experience pain complaints. Therefore, after identifying the pain and inconvenience of workers at the time of work it is necessary to immediately identify the worker's posture while doing his job. This is a recapitulation of the results of the risk level identification of workers with Rapid Entire Body Assessment on each work activity at the work station of pressing $\mathrm{t}$-shirt in CV Royaltrack Bandung.

Table 1. Results of the risk level identification

\begin{tabular}{|c|c|c|c|c|}
\hline $\begin{array}{l}\text { Work } \\
\text { Activity }\end{array}$ & $\begin{array}{l}\text { Left } \\
\text { right }\end{array}$ & $\begin{array}{l}\text { orREBA } \\
\text { Score }\end{array}$ & $\begin{array}{l}\text { Risk } \\
\text { Level }\end{array}$ & $\begin{array}{l}\text { Corrective } \\
\text { action }\end{array}$ \\
\hline \multirow{2}{*}{\multicolumn{2}{|c|}{$\begin{array}{l}\text { Worker s take t-Left } \\
\text { shirts to be } \\
\text { pressed Right }\end{array}$}} & 6 & Medium & $\begin{array}{l}\text { Needs } \\
\text { Improvement }\end{array}$ \\
\hline & & 6 & Medium & $\begin{array}{l}\text { Needs } \\
\text { Improvement }\end{array}$ \\
\hline \multirow{2}{*}{\multicolumn{2}{|c|}{$\begin{array}{l}\text { Worker s put t-Left } \\
\text { shirts on the } \\
\text { press machine Right }\end{array}$}} & 1 & $\begin{array}{l}\text { Can b } \\
\text { ignored }\end{array}$ & $\begin{array}{l}\text { eNo Need } \\
\text { Improve }\end{array}$ \\
\hline & & 1 & $\begin{array}{l}\text { Can b } \\
\text { ignored }\end{array}$ & $\begin{array}{l}\text { eNo Need } \\
\text { Improve }\end{array}$ \\
\hline \multirow{2}{*}{\multicolumn{2}{|c|}{$\begin{array}{l}\text { Worker } \mathrm{s} \text { take }{ }^{\text {Left }} \\
\text { masking paper }\end{array}$}} & 4 & Medium & $\begin{array}{l}\text { Needs } \\
\text { Improvement }\end{array}$ \\
\hline & & 4 & Medium & $\begin{array}{l}\text { Needs } \\
\text { Improvement }\end{array}$ \\
\hline \multirow{2}{*}{\multicolumn{2}{|c|}{$\begin{array}{l}\text { Worker s put Left } \\
\text { maskin g paper } \\
\text { on t- shirts to be } \\
\text { pressed }\end{array}$}} & 1 & $\begin{array}{l}\text { Can b } \\
\text { ignored }\end{array}$ & $\begin{array}{l}\text { eNo Need to } \\
\text { Improve }\end{array}$ \\
\hline & & 1 & $\begin{array}{l}\text { Can b } \\
\text { ignored }\end{array}$ & $\begin{array}{l}\text { eNo Need } \\
\text { Improve }\end{array}$ \\
\hline \multirow{2}{*}{\multicolumn{2}{|c|}{$\begin{array}{l}\text { Workers } \\
\text { holding the }{ }^{\text {Left }} \\
\text { press lever } \\
\text { ready to pressRight } \\
\text { the t- shirt }\end{array}$}} & 2 & Low & $\begin{array}{l}\text { Probably Needs } \\
\text { Improvement }\end{array}$ \\
\hline & & 2 & Low & $\begin{array}{l}\text { Probably Needs } \\
\text { Improvement }\end{array}$ \\
\hline \multirow{2}{*}{$\begin{array}{l}\text { Worker } \mathrm{s} \text { do } \mathrm{t}- \\
\text { shirt presses }\end{array}$} & Left & 3 & Low & $\begin{array}{l}\text { Probably Needs } \\
\text { Improvement }\end{array}$ \\
\hline & Right & 3 & Low & $\begin{array}{l}\text { Probably Needs } \\
\text { Improvement }\end{array}$ \\
\hline \multirow{2}{*}{$\begin{array}{l}\text { The worker lifts } \\
\text { the lever of the } \\
\text { machine }\end{array}$} & & 2 & Low & $\begin{array}{l}\text { Probably Needs } \\
\text { Improvement }\end{array}$ \\
\hline & Right & 2 & Low & $\begin{array}{l}\text { Probably Needs } \\
\text { Improvement }\end{array}$ \\
\hline
\end{tabular}

REBA observations have corresponded moderately to those of the OWAS method according to [8], from the recapitulation of the identification of the worker's risk level in the press work station only on the work activities of putting the t-shirt on the press machine, installing masking paper on the t-shirt to be pressed and taking the $\mathrm{t}$ - shirt from the press machine that

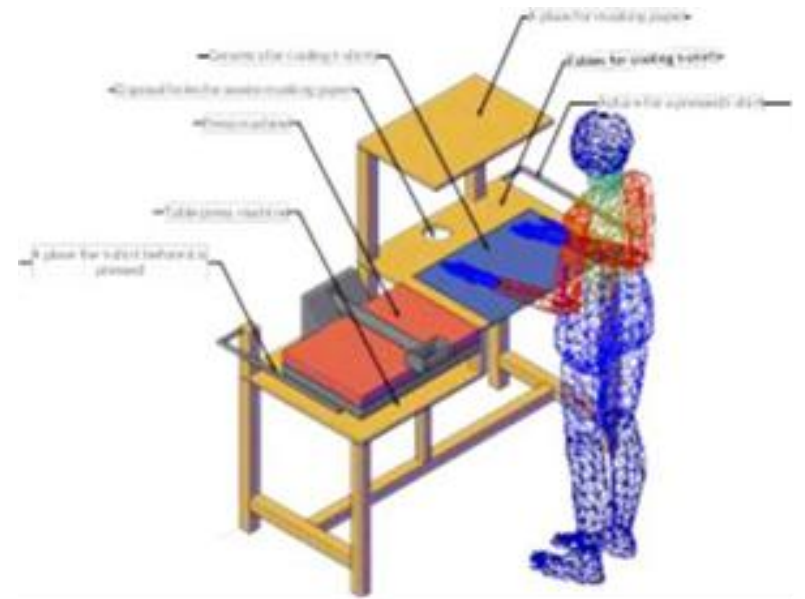

Figure 1. Design of work facility.

This is the Size Used for Designing Work Facilities:

Table 2. The size used for designing work facilities.

$\begin{array}{lrr}\text { Dimension } & \text { of, } & \\ \text { Working, } & \text { Facilities, } & \\ \text { Uody } & \text { DimensionsSize } & \text { Size } \\ \text { Design } & & \text { Tolerance }\end{array}$

\begin{tabular}{lll}
\hline Length of table pressLength of & press \\
machine & machine & \\
& $6 \mathrm{Cm}$ & $66 \mathrm{Cm}$
\end{tabular}

The length of the Long of masking. masking paper paper

$40 \mathrm{Cm}$

Long of table t- shirt

Long of t-shirts

$81 \mathrm{Cm}$

Long of ceramic Length of press cooler t-shirt machin

$60 \mathrm{Cm}$

T-shirt storage width The width of the palm of the hand -

$12 \mathrm{Cm}$

High of Elbow

High of table press Standing - High machine

press machine

$69 \mathrm{Cm}$

High of Place Stick Shoulder masking paper Stand - Width of High of table t- shirt $\begin{aligned} & \text { Dolm } \\ & \text { Elbow Standing }\end{aligned}$

$123 \mathrm{Cm}$ $85 \mathrm{Cm}$ High of ceramic ${ }_{\text {Elbow Standing }} \quad 85 \mathrm{Cm}$ cooler t-shirt ${ }^{2}$ Elbow Standing High of storage tee
shirt Table spread of press machine Front Hand Range
$62 \mathrm{Cm}$ 
$40 \mathrm{Cm}$

Wide of PlaceThe width of the masking paper masking paper

T-shirt table width

Front Hand Range

$62 \mathrm{Cm}$

\section{REFERENCES} Wide of ceramic Width of press
cooler t-shirt $40 \mathrm{Cm}$ machine

$62 \mathrm{Cm}$

The width of the teeshirt ${ }^{-}$Front Hand Range

(1)

The height of the

table leg support Eyes to the Floor -

$11 \mathrm{Cm}$

\section{CONCLUSION}

The observational techniques are broadly used in industry for their noninterference with the work performed, low price and simplicity of use [9]. The questionnaire showing $14.29 \%$ of worker's imbs.

who really do not have complaint of pain, while $85.71 \%$ of the workers' limb had complaint of pain to the level of complaints reached on level two (mildly ill) amounted $25 \%$ of the limb, level three (ill) amounted $53.57 \%$ of the limbs and level four (very ill) amounted to $7.14 \%$ of the limb. [10] used REBA as an assessment tool to assess the manual handling of practices in the supermarket industry in a major supermarket chain in New Zealand, from the result of the risk level of work identification that used Rapid Entire Body Assessment (REBA) method there are four out of ten work activities that have a risk on high level.
[1] Tarwaka, T., Sholichul, H.A. \& Lilik, S. 2004. Ergonomi Untuk Keselamatan, Kesehatan Kerja dan Produktivitas. Surakarta: UNIBA PRESS.

[2] Kroemer, K., Kroemer, H. \& Elbert, K.K. 2001, Ergonomics - How to Design For Ease and Efficiency. Prentice Hall: New Jersey.

[3] Hignett, S. \& McAtamney, L. 2000. Rapid entire body assessment (REBA). Applied Ergonomics 31(2): 201-205.

[4] Hignett, S. 1994. Using computerised OWAS for postural analysis of nursing work. In: Robertson. Contemporary Ergonomics. Taylor \& Francis,London: 253-258.

[5] Fransson-Hall, C., Gloria, R., Kilbom, A. \& Winkel, J. 1995. A portable ergonomic observation method (PEO) for computerised online recording of postures and manual handling. Appl Ergon 26 (2): 93-100.

[6] Karhu, O., Kansi, P. \& Kuorinka, I. 1977. Correcting working postures in industry: A practical method for analysis. Appl Ergon 8(4): 199-201.

[7] David, G. 2005. Ergonomic methods for assessing exposure to risk factors for work-related musculoskeletal disorders. Occupat Med 55: 190-199.

[8] Takala, E.P.I. Pehkonen, M., Forsman, G.A., Hansson, H. \& Mathiassen, S.E. 2010. Systematic evaluation of observational methods assessing biomechanical exposures at work. Scandinavian J. Work Environ. Health 36: 3-24.

[9] Kee, D. \& W. Karwowski. 2007. A comparison of three observational techniques for assessing postural loads in industry. Int J Occupat Safety Ergonom 13: 3-14.

[10] Coyle, A. 2005. Comparison of the rapid entire body assessment and the New Zealand manual handling 'hazard control record', for assessment of manual handling hazards in the supermarket industry. Work 24: 111116. 